九州大学学術情報リポジトリ

Kyushu University Institutional Repository

Studies on the flower pigments in snapdragon, Antirrhinum majus L. : II. Behaviour of a certain blocking gene for the aurone synthesis

Uemoto, Shunpei

Horticultural Laboratory, Department of Agriculture, Kyushu University

Nakao, Kazuo

福岡学芸大学

https://doi.org/10.5109/22779

出版情報 : 九州大学大学院農学研究院紀要. 14 (4)，pp.535-540，1968-11. Kyushu University バージョン：

権利関係 : 
Journal of Faculty of Agriculture, Kyushu University, Vol. 14, No. 4

September 30, 1968

\section{Studies on the flower pigments in snapdragon, Antirrhinum majus L.}

II. Behaviour of a certain blocking gene for the aurone synthesis

Shunpei Uемото and Kazuo N а к о

\section{Introduction}

A number of studies on the synthetic processes of floral pigments and on their genetic behaviours have been carried out with the garden snapdragon, Antirrhinum majus L., and, in consequence, this form has became the extensively biochemically analysed one in ornamentals. Variously coloured flower types, extending from pure white to crimson or orange, have been bred out in practice. But except the true albino flowers, a certain quantity of aurone pigments has occurred, usually localized to the palate petal. And such extensive occurence of aurone pigments in coloured petals is considered, no doubt, to give rise to a noteworthy complexity in the colour pattern of the garden snapdragon, being used as cut-flowers and as ornamentals in flower-bed.

It was made clear by T. A. Geissman and his coworkers (1954, 1955) that the aurone pigments are derived from their precursor $(\mathrm{C}$,$) through$ a certain definite pathway deviated from the synthetic processes of various other flavonoids. And, moreover, the aurone pigments in the garden snapdragon are characterised by J. B. Harborne (1963) to be consisted of two major components, i. e., aureusidin (4, 6, 3', 4'-tetrahydroxyaurone) and bracteatin $\left(4,6,3^{\prime}, 4^{\prime}, 5^{\prime}-\right.$ pentahydroxyaurone), and, furthermore, those two fractions of aurones are well known to occur usually at very high concentration in the palate region of corolla.

From the present study, the following items were made clear; 1) The process of aurone formation in flower petals in the snapdragon could be blocked by a definite gene which was derived as a mutant gene; 2) The genetic behavour of this gene ; and 3) A remarkable variation of flower colours in $F_{1}$ hybrids of snapdragon could be introduced by this aurone blocking gene. 


\section{Materials and methods}

The results presented in this haper have been derived from comparative studies on the two $F_{1}$ groups. That is, the first $F_{1}$ hybrid group, which was raised by the crosses between a true albino flowered strain (St. 161) possesing the blocking gene for aurone synthesis and certain normal coloured varieties (crimson and orange flowered) was used for the examination. And the $2 \mathrm{nd} \mathrm{F}_{1}$ hybrid group was raised by the similar crosses between a normal albino flowered strain (St. 171), which was derived from "Lucky Strike", and certain coloured varieties, and was assigned to the simultaneous test of pigmentation. The crimson coloured strain, St. 151, derived form "Balls Supreme Red" and orange coloured strain, St. 181, selected out of a certain line have been used as the parental lines for the $F_{1}$ hybrids. Those $F_{1}$ hybrid groups were raised and examined during the two growing seasons of 1959 and 1961, respectively.

The analytical procedures to make clear the qualitative nature and quantitative distributions of aurones in matured flower petals have been practiced as follows ; Fresh petals were first divided in two parts, palate and others, and those petals were dried at $45{ }^{\circ} \mathrm{C}$ for 12 hours, and powdered. Such testing samples were preserved in desiccator put in dark-room until the analysis. The paper-chromatography was utilized for the qualitative analysis of aurones and anthocyanins. On the other hand, the spectrophotometric measurement was performed to know relative quantities of those pigments. About $0.1 \mathrm{ml}$ of the crude extraction from $100 \mathrm{mg}$ of powdered dry sample with methanol containing $20 \mathrm{ml}$ of $\mathrm{HC} 1$ were spotted as $2 \mathrm{~cm}$ long on each sheet $(20 \mathrm{~cm} \times 20 \mathrm{~cm})$ of Toyo filterpaper No. 51. The paper was developed accendingly with upperlayer of the solvent, constituted as buthanol : acetic acid : water as 4: 1: 5, and the chromatograms were recognized as visible coloured spots or fluorescent spots under the ultraviolet light. Furthermore, each 2 cc of the crude extract was spotted linearly as long as $16 \mathrm{~cm}$ on the the filter paper and developed with the solvent of buthanol : acetic acid : water as $6: 1: 2$. After those sheets of chromatograms were separated into each bund of visible flavonoids, their constituents were re-extracted with $5 \%$ acetic methanol, and the absorption spectra with each compound were measured as optical density by Hitachi DU Spectrophotometer to define the relative aurone and anthocyanin concentrations.

\section{Experimental results}

As previously advanced, the two forms of $F_{1}$ hybrid were used for the test of floral pigmentation, i. e., the qualitative and quantitative analysis 
of aurone and anthocyanin pigments. Excepting that a trace of aurones was recognized in the quite restricted part of the palate region on the pink coloured flower, those $F_{1}$ hybrids which were raised by the crossing between an aurone blocking line (St. 161) and other normal cyanic lines, could not show the formation of aurones in all petals. On the contrary, the other $\mathrm{F}$, hybrid group raised by the similar crosses with the normal albino flowered line (St. 171) have formed common coloured flowers, in which a large amount of aurones was observed in their palate petals, and various co-coloured patterns with cyanic pigments have occurred in those regions. These colour patterns of $F_{1}$ hybrids are shown in Table 1, that

Table 1. Flower colour patterns as shown in two $\mathrm{F}_{1}$ hybrid groups (1959).

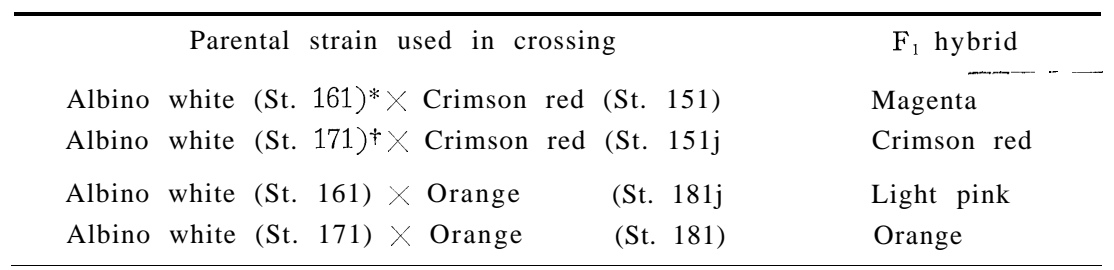

N.B. * The strain with the aurone blocking gene.

$\dagger$ The strain with normal white colour.

is, the former $F_{1}$ hybrid group showed a rather simple flower colour, but the latter group showed definite complexity in their flower colours, i. e., orange and crimson in palate petals. The fluorescent reaction of aurone spots on the chromatogram under the ultraviolet light are photographed in Fig. 1 and 2. The photographed patterns show aurone spots in those two groups of $F_{1}$ hybrids. The paperchromatographic patterns of aurones occurred in those two $F_{1}$ hybrids groups are quite different from each other. That is, it was clearly elucidated from the photographs that there are not any distinctive aurone pigments on the chromatographic patterns of the $F_{1}$ hybrids possesing the aurone-blocking gene, but the normal $F_{1}$ hybrids had two distinctive spots of the aurones, which could also indicate
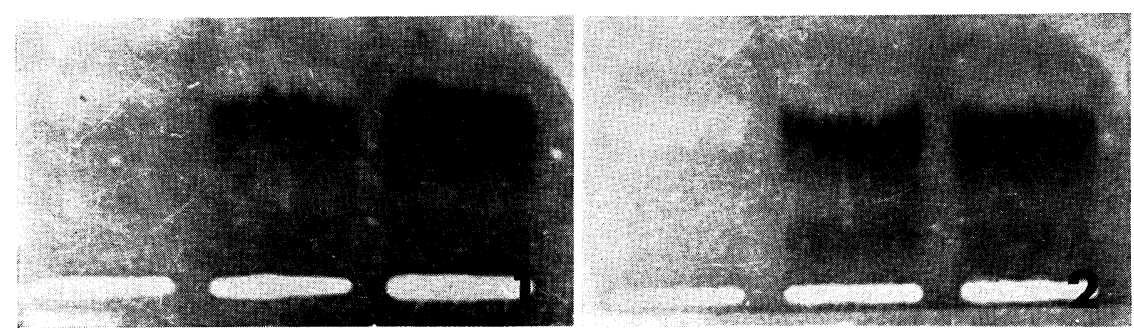

Figs. 1 and 2. Fluorescent reaction in paperchromatogram. 1: St. 1001, 2: St. 1010. 


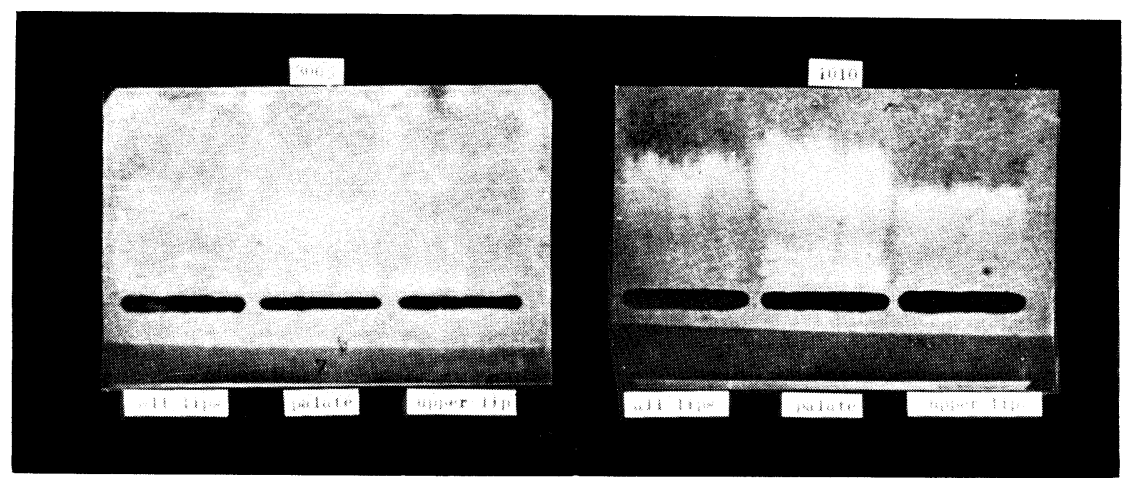

$3 \times \mathrm{F}_{1}$

Normal 2x $F_{1}$

Fig. 3. Fluorescent reaction in paperchromatogram. Right : normal diploid $F_{1}$. Left : triploid $F_{1}$.

clearly the presence of aureusidin glycoside on the higher spot and bracteatin on the lower spot.

Subsequently, the relative quantities of both aurone and anthocyanin pigments in two different regions of corolla, i. e., palate and others, in two different $F_{1}$ groups were measured with spectrophotometer and their values as shown in optical density are represented in Table 2 . In the result of

Table 2. Relative values* of spectrophotometric absorption in aurone and anthocyanin pigments extacted from various $F_{1}$ hybrids flower petals (1961).

\begin{tabular}{|c|c|c|c|c|c|c|}
\hline \multirow{2}{*}{ Flower } & \multicolumn{2}{|c|}{ Aureusidin } & \multicolumn{2}{|c|}{ Bracteatin } & \multicolumn{2}{|c|}{ Anthocyanin } \\
\hline & Palate & $\begin{array}{l}\text { Upper, lower } \\
\text { lips }\end{array}$ & Palate & $\begin{array}{l}\text { Upper, lower } \\
\text { lips }\end{array}$ & Palate & $\begin{array}{c}\text { Upper, lower } \\
\text { lips }\end{array}$ \\
\hline Magenta & $0.06 *$ & 0.00 & 0.02 & 0.00 & $0.63^{\text {(a) }}$ & $0.75^{\text {(a) }}$ \\
\hline Crimson & 1.40 & 0.20 & 0.27 & 0.02 & $0.52^{\text {(a) }}$ & $0.72^{\text {(a) }}$ \\
\hline Light pink & 0.09 & 0.02 & 0.03 & 0.01 & & $0.08^{(b)}$ \\
\hline Orange & 1.62 & 0.27 & 0.43 & 0.03 & & $0.06^{(b)}$ \\
\hline
\end{tabular}

N.B. * as shown in optical density.

(a) Antirrhinin, (b) Pelargonin.

works practiced during the growing season of 1959, the relative quantity of the pigments were given by the total of both the aurones, i. e., aureusidin and bracteatin, but in those of 1961 the result are shown with the values of two fractions of aurone individually. The results of quantitative analyses carried out in these seasons also revealed that the formation of aurone pigments did not take place in $F_{1}$ hybrids possesing the aurone blocking gene as similarly as shown previously by the chromatographic studies. On the contrary, much aurone pigments were formed in the normal 
$\mathrm{F}_{1}$ hybrid group. The former situation of trace existence of aurones in the restricted region of palates could not be fully defined in this study.

It was also made clear that the changes in the density of anthcyanin glycoside on the same petals in connection with the degree of aurone formation varied always in inverse proportion to the amount of aurones synthesized in this case as reported by Geissman et al. (1955).

\section{Discussion}

There was not any one report on the blocking gene for'aurone formation in snapdragon until the present time. The gene treated in this paper is considered to have a peculiar character for colour formations, that is to have no effect on the other synthetic processes of main flavonoids excepting aurone pigment. Furthermore, it may assumed from the present result that this gene will control the enzyme laid in the synthetic processes from chalcone to aureusidin as shown in Fig. 3. Consequently the formations of both aureusidin and bracteatin could be almost prevented at similar degree under the existence of this blocking gene.

Further, to make clear the hereditary behaviour of this gene, the quantitative analysis of aurones raised in the flower petals of the triploid $F_{1}$ hybrid, which was produced by the cross between an orange flowered tetraploid strain and an albino flowered diploid strain having the aurone blocking gene, was practiced. When this mutant gene was denoted by the letter $\mathrm{Ab}$, the genotype of this triploid $\mathrm{F}_{1}$ hybrid could be represented in the heterozygous constitution of $\mathrm{Ab} a b \mathrm{ab}$, namely, one $\mathrm{Ab}$ against two ab genes. Nevertheless, there could not almost obtained any aurones in palate petals of triploid $F_{1}$ hybrid (See Fig. 4). From these results, it could be safely suggested that this gene behaved as a completely dominant one.

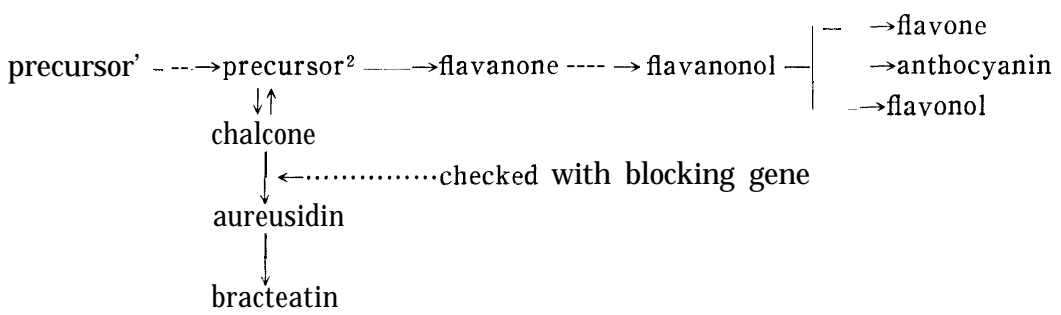

Fig. 4. Biosynthetic scheme for flavonoids in Antirrhinum majus.

\section{Acknowledgment}

The authors wish to express their hearty thanks to Prof. Dr. E. Fuku- 
shima for his valuable guidance and encouragement, given throughout this study, and also to Emer. Prof. H. It8 for his kind suggestions.

\section{Summary}

1. It was made clear that the process of aurone formation in the flower petals of garden snapdragon, Antirrhinum majus, L, could be affected by a definite gene which was induced mutationally in an albino white flower strain maintained throughout several generations by self-polination.

2. The crossing tests and the biochemical analyses, such as paper-chromatography and spectrophotometric measurement, with the aurone pigments in flower petals of $F_{1}$ hybrids have been carried out. The $F_{1}$ hybrids used were raised from the parallel crossing between an albino white strain provided with the present aurone blocking gene and certain normal cyanic strains, as well as between the normal albino strain and the same coloured strains.

3. In the former $F_{1}$ hybrid group, the process of aurone formation in petals was completely checked by this gene, which behaved as a simple dominant one, and those hybrid forms could contribute, in consequence, to the new breeding of variously mono-coloured beautiful snapdragon varieties.

\section{Literature cited}

1. Geisman, T. A., et. al. 1954 The chemistry of flower pigmentation in Antirrhinum majus color genotypes. I. The flavonoid components of the homozygous $\mathrm{p}, \mathrm{M}$, Y color types. Arch. Biochem. Biophys. 49. 368-388.

2. Geissman, T. A. 1962 The chemistry of flavonoid compounds. Pergamon Press. London and New York.

3. Harbone, J. B. 1963 Plant polyphenols. X. Flavone and aurone glycosides of $\mathbf{A n -}$ tirrhinum. Phytochem. $2: 327-334$.

4. Harbone, J. B. 1964 Biochemistry of phenolic compounds. Academic Press. London and New York.

5. Jorgensen, E. C. and T. A. Geissman 1955 The chemistry of flower pigmentation in Antirrhinum majus. III. Relative anthocyanin and aurone concentrations. Arch. Biochem. Biophys. 55 : 389-401.

6. Nakao, K. and S. Uemoto 1965 Studies on the Aower pigments in Antirrhinum majus. I. Relative contents of anthocyanin and aurone pigments in some tetraploid suapdragons. (In Japanese with English summary.) Sci. Bull. Fac. Agr. Kyushu Univ. 21: 353-361.

7. Uemoto, S. 1964 Studies on the $F_{1}$ hybrids of snapdragon, Antirrhinum majus. I. On the several ecological characteristics of various diploid forms. (In Japanese with English summary.) Sci. Bull. Fac. Agr. Kyushu Univ. 21 : 185-213. 